\title{
Seasonal trends and environmental controls of methane emissions in a rice paddy field in Northern Italy
}

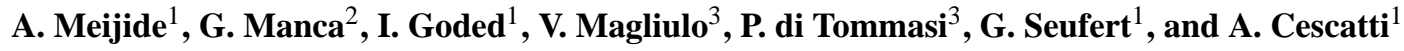 \\ ${ }^{1}$ European Commission - DG Joint Research Centre, Institute for Environment and Sustainability, \\ Climate Change and Air Quality Unit. Via Enrico Fermi 2749 I21027 Ispra (VA) Italy \\ ${ }^{2}$ National Research Council of Italy, Institute of Atmospheric Pollution Research, \\ Division of Rende, 87036-Rende, Italy \\ ${ }^{3}$ CNR-ISAFoM, Via Patacca, 80056 Ercolano, (Napoli), Italy
}

Received: 9 August 2011 - Published in Biogeosciences Discuss.: 6 September 2011

Revised: 30 November 2011 - Accepted: 2 December 2011 - Published: 21 December 2011

\begin{abstract}
Rice paddy fields are one of the greatest anthropogenic sources of methane $\left(\mathrm{CH}_{4}\right)$, the third most important greenhouse gas after water vapour and carbon dioxide. In agricultural fields, $\mathrm{CH}_{4}$ is usually measured with the closed chamber technique, resulting in discontinuous series of measurements performed over a limited area, that generally do not provide sufficient information on the short-term variation of the fluxes. On the contrary, aerodynamic techniques have been rarely applied for the measurement of $\mathrm{CH}_{4}$ fluxes in rice paddy fields. The eddy covariance (EC) technique provides integrated continuous measurements over a large area and may increase our understanding of the underlying processes and diurnal and seasonal pattern of $\mathrm{CH}_{4}$ emissions in this ecosystem.

For this purpose a Fast Methane Analyzer (Los Gatos Research Ltd.) was installed in a rice paddy field in the Po Valley (Northern Italy). Methane fluxes were measured during the rice growing season with both EC and manually operated closed chambers. Methane fluxes were strongly influenced by the height of the water table, with emissions peaking when it was above $10-12 \mathrm{~cm}$. Soil temperature and the developmental stage of rice plants were also responsible of the seasonal variation on the fluxes. The measured EC fluxes showed a diurnal cycle in the emissions, which was more relevant during the vegetative period, and with $\mathrm{CH}_{4}$ emissions being higher in the late evening, possibly associated with higher water temperature. The comparison between the two measurement techniques shows that greater fluxes are measured with the chambers, especially when higher fluxes are being produced, resulting in $30 \%$ higher seasonal es-
\end{abstract}

Correspondence to: A. Meijide

(ana.meijide-orive@jrc.ec.europa.eu) timations with the chambers than with the EC (41.1 and $31.7 \mathrm{~g} \mathrm{CH}_{4} \mathrm{~m}^{-2}$ measured with chambers and EC respectively) and even greater differences are found if shorter periods with high chamber sampling frequency are compared. The differences may be a result of the combined effect of overestimation with the chambers and of the possible underestimation by the EC technique.

\section{Introduction}

Methane $\left(\mathrm{CH}_{4}\right)$ is the third most important greenhouse gas after water vapour and carbon dioxide. Atmospheric $\mathrm{CH}_{4}$ concentration has been increasing during the last several hundred years due to changes in agricultural practices and other anthropogenic activities (Dlugokencky et al., 1994; Etheridge et al., 1998; Ferretti et al., 2005). Recent studies have shown that, if the effect of aerosols is also taken into account, the relative contribution of $\mathrm{CH}_{4}$ to climate change is greater than what was previously estimated by the Intergovernmental Panel on Climate Change (IPCC) Fourth Assessment Report (AR4) (Shindell et al., 2009).

Rice paddy fields are one of the largest anthropogenic sources of $\mathrm{CH}_{4}$. Irrigated rice fields are estimated to contribute between $6 \%$ and $8 \%$ (Cole et al., 1995) of the global $\mathrm{CH}_{4}$ emission (Houghton et al., 1995) as they have a high emission rate and occupy large areas, mainly in Asia, but also in Mediterranean regions in Europe (IPCC, 2003). Italy is the largest rice producer in Europe .(FAO, 2002) and this production is concentrated in the Po Valley (Ferrero, 2007), where this study took place.

Published by Copernicus Publications on behalf of the European Geosciences Union. 
Field experiments in rice paddies have shown that there is a large spatio-temporal variability on $\mathrm{CH}_{4}$ emissions that have to be accounted for in order to produce robust estimates of yearly budgets (Holzapfel-Pschorn and Seiler, 1986; Schfitz et al., 1989; Schutz et al., 1989; Sass et al., 1991). In agricultural fields, $\mathrm{CH}_{4}$ is usually measured with the closed chamber technique, resulting in discontinuous series of measurements performed over a limited area, that generally do not provide sufficient information on the short-term variation of the fluxes. Moreover, these samples are subject to uncertainties associated with the use of chambers (Mosier, 1990), which may interfere with the production and transport of the gas studied. However, closed chambers have the advantage of detecting low fluxes, of being easy to manipulate and of low cost. Therefore, this technique has commonly being used to estimate $\mathrm{CH}_{4}$ emissions, and has already been used in rice paddy fields (Holzapfel-Pschorn and Seiler, 1986). Alternatively, the aerodynamic technique of eddy covariance (EC) provides continuous measurements, without interfering with the processes of gas exchange between the sources and the atmosphere. This technique is commonly used for the estimation of $\mathrm{CO}_{2}$ and $\mathrm{H}_{2} \mathrm{O}$ and energy fluxes, but its use for the measurement of $\mathrm{CH}_{4}$ fluxes is less common, as adequate analyzers have only recently became available.

The EC technique provides integrated continuous measurements over a large area and may increase our understanding of the underlying processes regulating the seasonal and diurnal pattern of $\mathrm{CH}_{4}$ emissions in a certain ecosystem. Some studies have already been carried out with this technique, showing that it is adequate for the estimation of $\mathrm{CH}_{4}$ fluxes (Rinne et al., 2007; Hendriks et al., 2008; Hendriks et al., 2009; Kroon et al., 2009; Long et al., 2010; Schrier-Uijl et al., 2010; Baldocchi et al., 2011; Detto et al., 2011; Herbst et al., 2011). However, so far there are few studies where the $\mathrm{EC}$ technique has been used to measure $\mathrm{CH}_{4}$ emissions from rice paddy fields (Werle and Kormann, 2001; Detto et al., 2011).

Comparison of eddy covariance and chamber-based methods have previously been made for net ecosystem exchange of $\mathrm{CO}_{2}$ (balance between respiratory and assimilatory processes) (Wang et al., 2010), pointing that further studies are required as sources of error from the two techniques are not clearly understood. Schrier-Ujil et al. (2010) compared $\mathrm{CH}_{4}$ fluxes measured with both methods in a peat-land and concluded that fluxes were comparable when all the landscape elements involved in the EC flux were considered in the scaling up from chamber measurements. Werle and Kormann (2001) also performed a similar comparison in a rice paddy field, during a short campaign of one week, resulting in great differences between measurement techniques. In this study the comparison was carried out using eddy covariance and chamber-based methods to measure $\mathrm{CH}_{4}$ fluxes in a rice paddy field during the growing season and the period after harvest.
The objectives of our study were to:

1. Compare the eddy covariance technique and closedchamber-based method for estimating $\mathrm{CH}_{4}$ fluxes in this ecosystem;

2. Identify the environmental drivers and the diurnal and seasonal patterns of $\mathrm{CH}_{4}$ fluxes in a rice paddy field; and

3. Evaluate the differences in the $\mathrm{CH}_{4}$ surface budgets produced with the two techniques and quantify the seasonal $\mathrm{CH}_{4}$ emissions from a rice paddy field in northern Italy.

\section{Materials and methods}

\subsection{Study site}

The study site is located in an agricultural field in the Po Valley, in Northern Italy, in the municipality of Torre Beretti and Castellaro (Pavia) $\left(45^{\circ} 04^{\prime} 12.17^{\prime \prime} \mathrm{N}, 8^{\circ} 43^{\prime} 03.08^{\prime \prime} \mathrm{E}\right.$, $88 \mathrm{~m}$ a.s.l). The site extends for $400 \times 700 \mathrm{~m}$ and it is part of a farm which cultivates rice and corn for silage in 700 ha of irrigated land.

The study was carried out in 2009, when the site was cultivated with rice (Oryza sativa var. Selenio). Prior to initiation of the study, the site was cultivated with maize (Zea mais) in 2006 and with rice since 2007.

The soil is a Calcic Gleysol (FAO, 1998), with a loam to clay-loam texture. In 2009 the annual rainfall was $658 \mathrm{~mm}$ and the mean annual temperature $12.9^{\circ} \mathrm{C}$. The field was flooded on day 104 (mid April), and a first sowing took place on day 107. The sowing was not successful so the soil was dried, tilled, and re-sowed at the end of April (day 120). Sowing was carried out in water with a centrifuge sowing machine. Then the water was removed to allow for the seeds to get to the soil and germinate. Once plants had germinated, the field was re-flooded (early June, day 160) and water was kept during the rest of the growing season. A total of 131 $(61+70) \mathrm{kg} \mathrm{Nha}^{-1}$ were applied as fertilizer in 2 different events, on days 91 and 183 (beginning of April and beginning of July), as N-P-K (30-0-30) and urea respectively. The standing water level fluctuated during the flooded periods due to the continuous water flow through the rice field, a typical management practice for this crop. At the beginning of September the water was removed from the field, and the rice was harvested on day 265 (end of September).

\subsection{Chamber flux measurements}

Manually operated closed chambers were used for the measurement of $\mathrm{CH}_{4}$ fluxes from the soil. In order to cover for spatial variability, the measured fluxes were calculated from the average of 8 different chambers distributed along the field. Chambers were placed in two groups of four at different sides of a small dike (1-2 $\mathrm{m}$ wide) where the eddy 
covariance tower was installed, and each group was on average at 25 and $45 \mathrm{~m}$ from the EC tower $(20 \mathrm{~m}$ between each group). Chambers within each of the groups were at a distance of 2-3 $\mathrm{m}$. Stainless steel rings were inserted $5 \mathrm{~cm}$ into the soil at the beginning of the experiment. They were removed and reinstalled for the fertilization events and were then kept in place throughout the experimental period. The chambers consisted of a Plexiglass cylindrical structure (15 or $30 \mathrm{~cm}$ height) covered with a Teflon film $(50 \mu \mathrm{m})$. These structures were fitted to the stainless steel rings, to avoid soil disturbance. The chamber surface was $0.11 \mathrm{~m}^{2}$ while the volume was modified during growing season, according to the growing of rice plants of each plot, by adding 15 or $30 \mathrm{~cm}$ height rings on top of those fitted to the stainless steel rings. The chambers were closed during the sampling period with Plexiglas lids. A syringe was fitted to the Plexiglas structure in order to remove the samples.

To estimate $\mathrm{CH}_{4}$ fluxes, 4 different samples were taken during the period when the chambers were closed, the first one after chamber closure, second and third at regular intervals during chamber closure and the fourth at the end of the sampling period. Chambers were ususally closed for a maximum of $60 \mathrm{~min}$, except at the beginning of the growing season, when closing period was increased to $90 \mathrm{~min}$ because both fluxes and temperature were very low. $100 \mathrm{ml}$ samples were removed from each chamber with a syringe, and were then transferred into $20 \mathrm{ml}$ glass vials, flushing the sample through the vial with 2 needles. Temperature in the chamber headspace during all closure time was measured with an electronic temperature sensor (Greisinger, GTH 175/MO) and recorded when samples were removed. Air samples were collected every 5-7 days in the periods when the rice was flooded, and every 2-4 weeks during the rest of the experimental period, from the 3 April until 9 December. Samples were always taken around 12 a.m. (midday).

Methane concentration in the vials was then measured by gas chromatography (GC) with a Shimadzu GC 14B equipped with a packed column Porapak $\mathrm{Q}$ and a Flame Ionization Detector (FID). The GC was configured to allow for the simultaneous measurement of $\mathrm{N}_{2} \mathrm{O}$, so it was also equipped with an electron capture detector installed in line with the FID. The temperatures of the injector, oven and detector were 100,40 and $340^{\circ} \mathrm{C}$ respectively. Samples were automatically injected into the GC as reported in Leip (2000).

Methane fluxes were calculated from the rate of the change of $\mathrm{CH}_{4}$ concentration in the chambers headspace during the closure time. This was estimated as the slope of the linear regression between concentration (after corrections for temperature using the ideal gas law in order to compensate for the increases of temperature headspace during chamber closure) and time and accounting for the ratio between chamber volume and soil surface area (MacKenzie et al., 1998). Only those chambers where there was a linear relation $\left(r^{2}>0.75\right)$ for at least 3 of the sampling points were used for the calculation of the fluxes. When the last sampling point was not lin- ear with the previous three the sampling point was rejected. Cumulative $\mathrm{CH}_{4}$ fluxes measured with the chambers were estimated by linear interpolations between sampling dates.

\subsection{Eddy covariance flux measurements}

Methane fluxes were measured from the 9 April to 31 December 2009 using the EC technique (Baldocchi et al., 1988; Baldocchi et al., 1996). The three components of the wind vector were measured by a Gill HS-100 ultrasonic research anemometer (GILL Instruments Limited, Hampshire, UK) positioned at a height of $2.2 \mathrm{~m}$ above soil surface. Methane mixing ratio was measured by a RMT-200 fast methane analyzer (FMA) from Los Gatos Research Ltd. In order to obtain a response time of 0.2 seconds, the FMA was operated in high flow mode by connecting the outlet of the analyzer to a dry scroll pump (Edwards XDS 35i). In addition to the internal filter from the FMA, a second filter with the same pore size $(2 \mu \mathrm{m})$ was placed at the sampling point close to the anemometer head in order to prevent dust, aerosols, insects and droplets from entering the tubing. Analogue outputs from the FMA were digitally converted, coupled with wind speed measurements and logged on a portable computer. Carbon dioxide and water vapour concentrations were measured by a close path infrared gas analyzer, (Li-6262, LI-COR Lincoln, NE, USA) with a response time of $0.2 \mathrm{~s}$ for $\mathrm{CO}_{2}$ and $0.3 \mathrm{~s}$ for $\mathrm{H}_{2} \mathrm{O}$. The EC set-up formed by the anemometer and $\mathrm{CO}_{2} / \mathrm{H}_{2} \mathrm{O}$ analyzer has been running since July 2006 and is further described in Rossini et al. (2010).

A three rotations scheme was applied to each averaging period following Mc-Millen (1988) in order to place the anemometer into a streamwise coordinate system. Covariances between wind velocity components and concentrations were calculated with a time step of 30 min using a linear detrending algorithm (Gash and Culf, 1996). The time lag required to draw air from the sampling point to the analyzer was determined by maximizing the correlation between vertical wind speed and concentrations (Goulden et al., 1996). The average time lag for $\mathrm{CH}_{4}$ was 1 second but in some short periods it increased because of the dust accumulated in the internal filter. Frequency response losses were corrected using empirical transfer functions, as described in Aubinet et al. (2000). Finally, a storage term was added to the calculated $\mathrm{CH}_{4}$ fluxes for the determination of net ecosystem fluxes, calculated as difference between $\mathrm{CH}_{4}$ concentrations in two consecutive half hour periods.

Methane fluxes have been corrected according to the Webb-Pearman-Leuning (WPL) theory to compensate for the air density fluctuation arising from heat and water vapour fluxes. Temperature fluctuations were assumed negligible, while fluctuations of water vapour were estimated with the frequency corrected water fluxes measured by the Li-6262. The attenuation of atmospheric water fluxes in the FMA setup was estimated assuming that these fluxes undergo the same spectral attenuation of the WPL-uncorrected methane 
fluxes. We estimated the spectral attenuation for $\mathrm{CH}_{4}$ and $\mathrm{H}_{2} \mathrm{O}$ flux by the empirical method described in Aubinet et al. (2000). This method assumes that the heat flux measured by the anemometer is free from frequency losses. For this purpose the ratio between the cospectrum of heat flux and the cospectrum of a second scalar flux (as $\mathrm{CH}_{4}$ flux) is used to estimate the transfer function that corrects the fluxes for the underestimation due to spectral attenuation.

A flux footprint analysis was carried out at the site by Rossini et al. (2010) for the flux measurements of $\mathrm{CO}_{2}$ and water vapour fluxes. The study indicated that more than $80 \%$ of the measured scalar flux originates from the target rice field. We performed a similar footprint analysis for $\mathrm{CH}_{4}$ fluxes using the analytical model described in Neftel et al. (2008). In order to evaluate the homogeneity of the source area, the rice paddy was split in four rectangular areas centred on the flux tower and having nearly the same area $(80 \times 180 \mathrm{~m})$. We compared the average $\mathrm{CH}_{4}$ flux coming from the area composed by 2 of the rectangular areas and the average flux from from the remaining two. The comparison was performed using the t-test (significance level of $5 \%$ ) on data collected during the period 10-23 July, when the daily pattern of meteorological conditions was steady. Flux averages were calculated using half-hourly data from 10:00 to 13:00 UTC in order to avoid biases due to changing meteorological conditions. Moreover half-hour fluxes were considered in the analysis only if the footprint contribution of the source area was higher than $80 \%$. The t-test showed that fluxes coming from the two areas were not different ( $p=0.06-0.08$ ) independently on the grouping of the rectangular areas.

Two tests were performed in order to evaluate the overall quality of eddy covariance fluxes: integral turbulence test and steady state test (Foken and Wichura, 1996). Results from both tests were combined in order to get an overall quality flag for each half-hour period. Three categories were established and data belonging to class 2 (steady state deviation $>100 \%$ or integral turbulence characteristics deviation $>100 \%$ ), were discarded.

Data were also filtered according to friction velocity $\left(u^{*}\right)$ to avoid the possible underestimation of fluxes in stable atmospheric conditions. The critical $u^{*}$ threshold was set to $0.045 \mathrm{~m} \mathrm{~s}^{-1}$ according to Rossini et al. (2010). In addition, data were filtered on the basis of the pressure inside the measurement cell of the FMA in order to exclude periods when filter clogging increased the lag time. The pressure threshold was set at 110 Torr in order to maintain the response time at $0.2 \mathrm{~s}$. Finally data were smoothed using a $2 \mathrm{~h}$ moving window filter to reduce data inherent noise (Damm et al., 2010).

Data series have been gap-filled following the look-up table (LUT) method in accordance with Falge et al. (2001), and considering both the co-variation of fluxes with meteorological drivers and the mean diurnal variation. The LUT was created using environmental variables which showed the highest correlations with fluxes (soil and air temperature and depth of the water table) as well as some other considered relevant, such as radiation and rainfall.

\subsection{Environmental variables}

Meteorological variables were measured every $30 \mathrm{~s}$ and then averaged and stored as half-hour mean value. Photosynthetic photon flux density (PPFD) was measured by means of a quantum sensor (LI-190, LI-COR Inc.) and sunshine sensor (BF3, Delta T); air temperature (Tair) was measured with a shielded thermo hygrometer (model RFT-2, UMS, Munich, Germany). Net radiation was measured by a net radiometer (model CNR1, Kipp \& Zonen; Delft, The Netherlands) installed at $3.5 \mathrm{~m}$ above ground and the heat flux into the soil by a heat flux plate (model HFP01, Hukseflux; Delft, The Netherlands) installed $4 \mathrm{~cm}$ below ground. Soil heat storage between soil surface and the heat flux plate sensor depth was estimated with a temperature profile $(3.5,7.5$ and $15 \mathrm{~cm})$ of UMS-Th2-h and assuming a volumetric heat capacity of $2.99 \times 10^{6} \mathrm{~J} \mathrm{~m}^{-3} \mathrm{~K}^{-1}$ for wet soil (Hillel, 1982). Soil water content was measured with a TDR (TRIME-EZ, IMKO) installed at a depth of $16 \mathrm{~cm}$ and the depth of the soil water table was monitored with a Baro Diver (Schlumberger Water Services) and derived from the pressure at $110 \mathrm{~cm}$ below the soil surface minus the pressure at the soil surface.

\subsection{Canopy structural parameters}

Rice phenology was assessed during the development of the crop in 5 fixed sampling plots close to the EC flux tower. Rice phenology was evaluated according to the extended BBCH (Biologische Bundesanstalt, Bundessortenamt and Chemical industry) scale (Lancashire et al., 1991; Meier, 1997) based on Zadok et al. (1974) cereal code, on 5 plants from each sampling plot. The BBCH growth stages were grouped into three basic growth phases of the rice plant: vegetative (from germination to panicle initiation), reproductive (from panicle initiation to flowering) and ripening (from flowering to senescence). The dominant phenological phase at the five sampling plots was considered representative of the whole rice field.

The phenological phases were used to divide the temporal series of $\mathrm{CH}_{4}$ fluxes into 5 data sets: before rice was sown (days 97 to 120), vegetative (days 121 to 165), reproductive (days 166 to 207), ripening (days 208 to 264) and after rice harvest (265 to 365 ).

\subsection{Statistical analysis}

Statistical analysis and data filtering were carried out with Statistica (v. 8, StatSoft inc.). Linear regression analyses $(P<0.05)$ were performed to determine relationships between $\mathrm{CH}_{4}$ emissions with the measured environmental variables. The statistical significance of the differences between the cumulative emissions measured with different techniques was tested by the analysis of variance (ANOVA, $P<0.05$ ). 


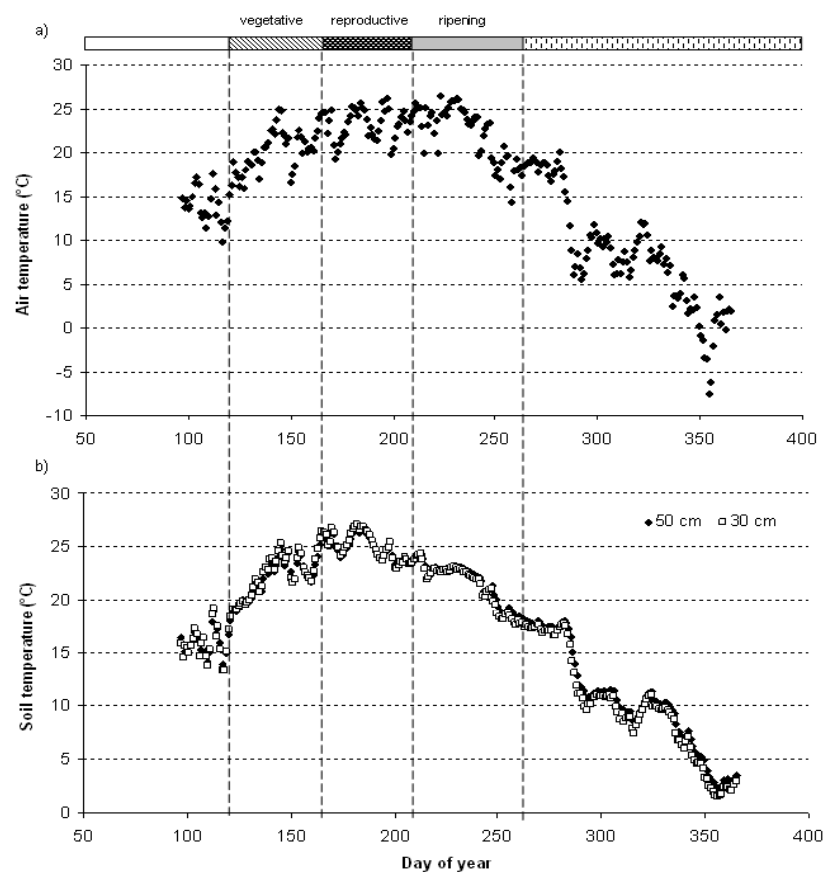

Fig. 1. Seasonal trends of the daily average air (a) and soil (b) temperatures at depths of 50 and $30 \mathrm{~cm}$.

Comparison of data obtained with both methods was also carried out by linear regressions (fluxes measured with chambers against average of fluxes measured with EC during the period when chamber measurements were taken), by the Bland-Altman method (Altman and Bland, 1983) and comparing seasonal integrals during the periods when sufficient data coverage was available for both measurement techniques.

\section{Results}

\subsection{Environmental conditions and $\mathrm{CH}_{4}$ fluxes from the rice field}

During the experiment large variations on daily average air temperature were observed, with values ranging from 10 to $15^{\circ} \mathrm{C}$ in April, increasing up to $26^{\circ} \mathrm{C}$ in August and then decreasing until $-7^{\circ} \mathrm{C}$ at the end of December (Fig. 1a). A similar pattern was observed in the daily average soil temperature (Fig. 1b), with minimum temperatures always above $1.5^{\circ} \mathrm{C}$ and maxima reaching $27^{\circ} \mathrm{C}$. Soil temperatures are strictly coupled with air temperatures, except when major changes in the level of the water table are occurring (e.g. on day 104 the first flooding decreased soil temperature).

Soil was water logged (soil water content at about $60 \%$ ) during most of the observation period (Fig. 2a). Water table depth measurements started at the beginning of June (Fig. 2b). From that moment, the water table increased,

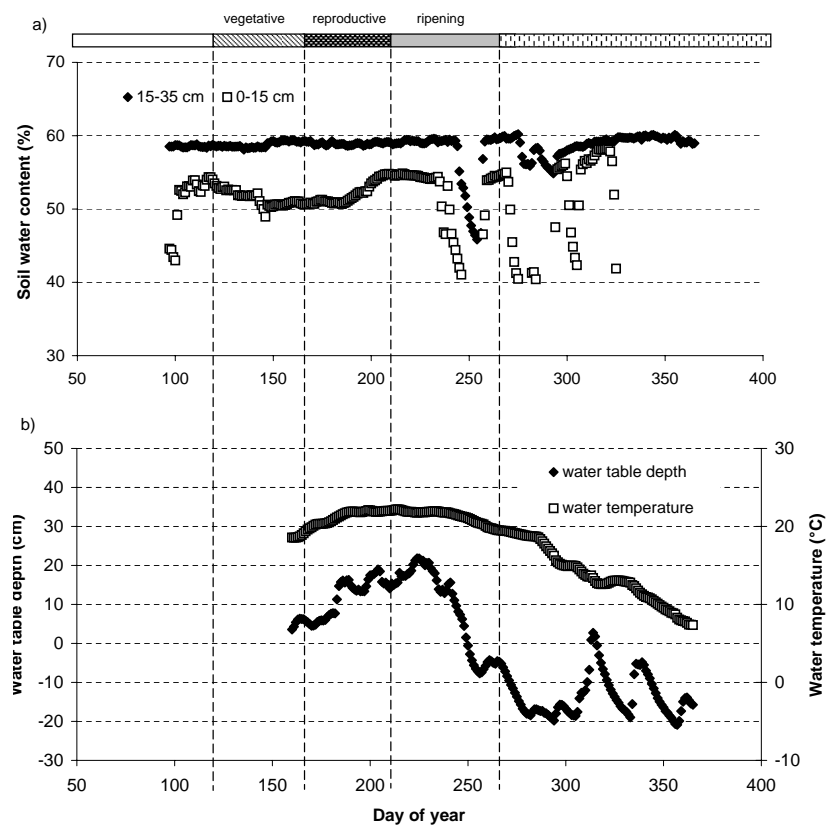

Fig. 2. Daily average soil water content at $0-15 \mathrm{~cm}$ and $15-35 \mathrm{~cm}$ (a) and depth of the water table (b). Positive values indicate that the water table was above the soil surface.

reaching a maximum of $21 \mathrm{~cm}$ in mid August (day 225). The water level started to decrease in coincidence with the second half of the ripening period, until early September when the soil was no longer submerged (day 250). Subsequent increases of water table depth were a consequence of intense rainfall and not of flooding.

Methane half-hour fluxes varied largely along the experimental period (Fig. 3). $\mathrm{CH}_{4}$ emissions were very low (on average $0.23 \mu \mathrm{mol} \mathrm{CH}_{4} \mathrm{~m}^{-2} \mathrm{~s}^{-1}$ ) until the end of May, with net $\mathrm{CH}_{4}$ oxidation taking place at certain moments during this first period. When the field was flooded and the rice sown (day 120), emissions started to increase. The highest half-hourly emissions were measured in July and August, during the ripening period (maximums of 0.98 and $0.72 \mu \mathrm{mol} \mathrm{CH}_{4} \mathrm{~m}^{-2} \mathrm{~s}^{-1}$ respectively). At the end of August emissions decreased and remained very low (between -0.02 and $0.12 \mu \mathrm{mol} \mathrm{CH} \mathrm{Cm}^{-2} \mathrm{vs}^{-1}$ ) till the end of the year. Analysis of variance indicated statistically significant differences in the fluxes within the different stages of development of rice plants $(p<0.001)$. Methane fluxes measured with chambers followed a similar pattern as those measured with eddy covariance. No significant differences $(p<0.05)$ were found between chambers placed at different sides of the dike.

Giving that the number of observations obtained with EC is much larger than with static chambers, the analysis of relationships between fluxes and environmental variables have been carried out exclusively with EC data. 


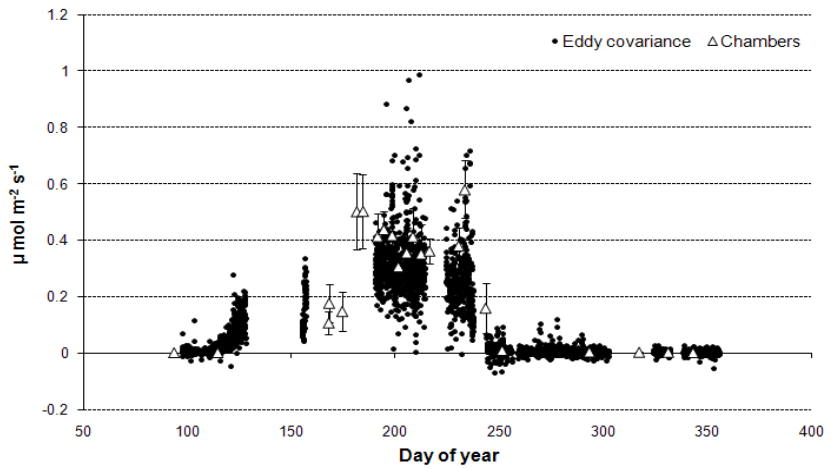

Fig. 3. $\mathrm{CH}_{4}$ fluxes derived from measurements with closed chambers (open triangles) and eddy covariance.

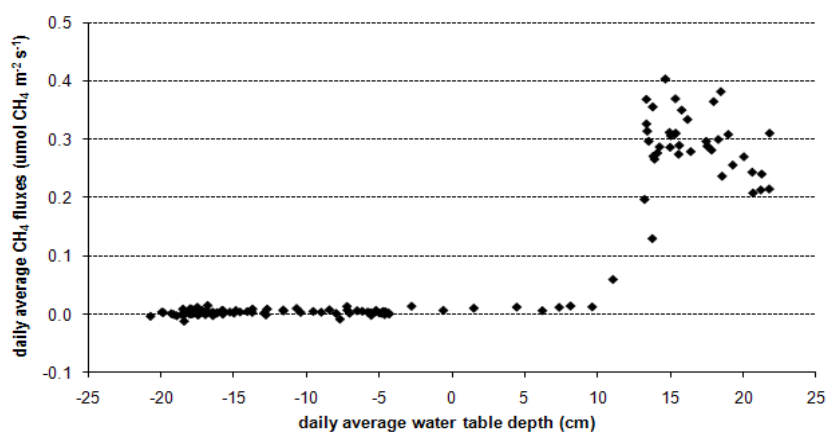

Fig. 4. Relationship between $\mathrm{CH}_{4}$ fluxes and depth of the water table.

Significant positive correlations were found between $\mathrm{CH}_{4}$ fluxes and the depth of the water table $(r=0.65)$. Plotting the daily average depth of the water table against the daily average $\mathrm{CH}_{4}$ flux (Fig. 4) we observed that fluxes were close to zero when the depth of the water table was below $10 \mathrm{~cm}$. Highest $\mathrm{CH}_{4}$ fluxes $\left(0.20-0.40 \mu \mathrm{mol} \mathrm{CH}_{4} \mathrm{~m}^{-2} \mathrm{~s}^{-1}\right)$ were produced when the water level had risen above $12 \mathrm{~cm}$.

Correlations between $\mathrm{CH}_{4}$ fluxes and soil or air temperature were not significant when applied to the whole experimental period and neither when applied separately to periods with or without the crop. However, when the data set was partitioned in classes of day and night (based on associated measurements of light intensity (PPFD) being greater or lower than $50 \mu \mathrm{mol} \mathrm{m} \mathrm{m}^{-2} \mathrm{~s}^{-1}$ ) and according to the plant development stages (ie. vegetative, reproductive and ripening), high correlations were found between $\mathrm{CH}_{4}$ fluxes and soil temperature. Binning the data in $2{ }^{\circ} \mathrm{C}$ classes of soil temperature, strong positive correlations were found both for the day and night during the vegetative period $\left(r^{2}=0.99\right.$ and $r^{2}=0.98$ respectively). Correlations were considerably lower during the reproductive period $\left(r^{2}=0.51\right.$ and $r^{2}=0.68$ for day and night respectively) and high again in the ripening period $\left(r^{2}=0.87\right.$ and $r^{2}=0.94$ for day and night respectively).

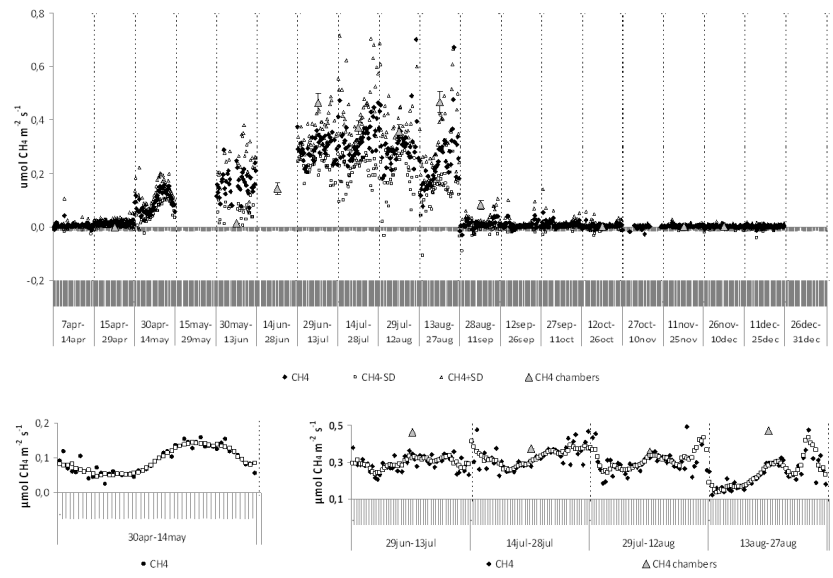

Fig. 5. Average daily variation during 2 weeks periods (with detail of $\mathrm{CH}_{4}$ fluxes in periods with higher emissions). Data are binned by time of day and then averaged for 2 weeks periods. The standard deviations are calculated on data passing the quality test on turbulence intensity.

Eddy covariance fluxes averaged over a 2 weeks period showed a diurnal cycle in periods of high emissions (Fig. 5). During the vegetative period (bi-week between 30 April and 14 May), the diurnal trend followed the temperature cycle with an increase of emissions between 9-10am, maximum between $15-20 \mathrm{~h}$ and lower emissions during the night. During the reproductive and beginning of the ripening period the maximum emissions were reached earlier during the day (11-17 h) and decreased during the rest of the day. During the rest of the ripening period (be-weeks in the period from 29 July to 27 August) a similar diurnal cycle was observed but with two different peaks, one in the late evening and a second one around $23 \mathrm{~h}$.

\subsection{Comparison between chamber and eddy covariance measurements of $\mathrm{CH}_{4}$}

From the whole eddy covariance data series (7 April 2009-31 December 2009), high quality data were obtained for $31 \%$ of the experimental period. Long interruptions ( $>7$ days) due to instrument failure were responsible of $40 \%$ of data gaps. Considering only periods when the system was properly running, after filtering for low turbulence and data spikes, $53 \%$ of the data were classified as of good quality.

The footprint analysis has shown that fluxes measured with the eddy covariance originate within the rice paddy and cover the area where the chambers were located (Rossini et al. 2010). In addition the analysis of the spatial distribution of emission in the footprint based on the methodology proposed by Neftel et al. (2008) demostrates that methane fluxes are homogeneously distributed in the rice field. Alltoghether these results confirm the validity of the experimental setup and support the intercomparison of emissions retrived with the two tecniques. 


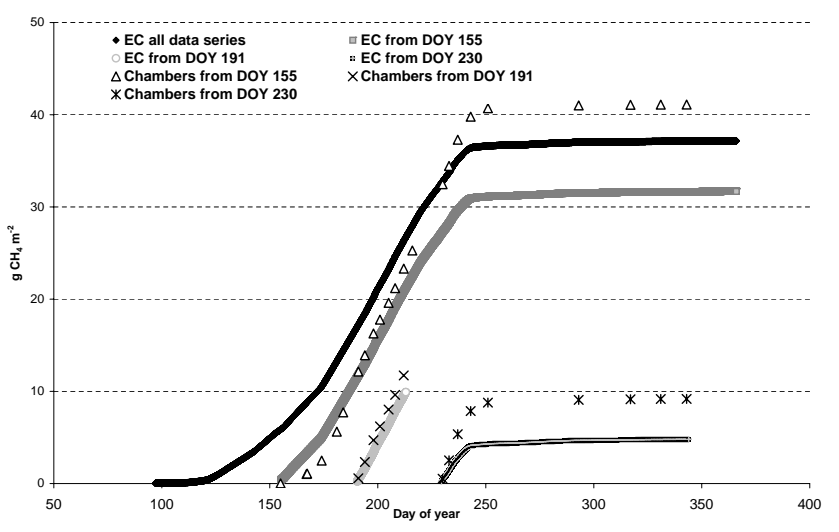

Fig. 6. Seasonal integrals of $\mathrm{CH}_{4}$ fluxes measured with eddy covariance and with chambers (during all the experimental period, from DOY 155 and periods DOY 191-213 and DOY 230-244).

During the experimental period we obtained 23 measurements from the closed chambers. The comparison between the data sets obtained with the two techniques shows that both data series follow a similar temporal pattern (Fig. 3). However, we can also observe that fluxes measured with the chambers are on average higher than those measured with EC for the same period of the day.

The linear regression between the punctual data obtained with the two measurement techniques $\left(\mathrm{CH}_{4} \mathrm{chmb}=1.265 \mathrm{CH}_{4 \mathrm{EC}}-5.8610^{-3}, \quad R^{2}=0.969\right)$ indicates a good agreement between them. The value of the intercept is close to zero, indicating that both methods are equally effective in detecting the shift from sink to source. The slope shows that fluxes measured with chambers were on average $\sim 26 \%$ higher than those observed with EC. However, the high $R^{2}$ might be an effect of comparing very low off season fluxes with the high fluxes of the growing period.

To further compare the results of the two measurement techniques, the Bland-Altman test was carried out. When the test was applied on the whole data series, we observed that the differences between the results of the two methods (calculated as average $\pm 2 *$ standard deviation) ranged between -0.06 and 0.16 . When the analysis was performed separately on low fluxes $\left(<0.02 \mu \mathrm{mol} \mathrm{CH}_{4} \mathrm{~m}^{-2} \mathrm{~d}^{-1}\right)$ differences between the 2 techniques ranged between -0.02 to 0.02 , while for the higher fluxes these differences ranged between -0.02 to 0.18 . This analysis shows that for low fluxes the differences between measurement techniques are limited and on average null, while for higher fluxes differences between the results obtained with the 2 methods increase linearly.

The comparison of the two measurement techniques has been extended to seasonal integrals (Fig. 6). For this purpose fluxes have been cumulated from 4 June 2009 (day 155 to 343 ), as from this moment chamber data started to be regularly collected. A total of $31.7 \mathrm{~g} \mathrm{CH}_{4} \mathrm{~m}^{-2}$ were measured with EC, while $41.1 \mathrm{~g} \mathrm{CH}_{4} \mathrm{~m}^{-2}$ were measured with chambers for the same period. This resulted in cumulative fluxes estimated from chamber measurements $30 \%$ higher than those from the eddy covariance. Comparisons between measurement techniques over two intervals with no gaps in the eddy covariance series (day 191-213 and day 230-244) resulted in 18 and $91 \%$ higher fluxes measured with chambers for the two periods, respectively (Fig. 6). If data from the beginning of EC measurements is considered, the cumulated $\mathrm{CH}_{4}$ flux is $37.2 \mathrm{~g} \mathrm{CH}_{4} \mathrm{~m}^{-2}$.

\section{Discussion}

\subsection{Seasonal variations of $\mathrm{CH}_{4}$ fluxes from the rice field}

Large variations in $\mathrm{CH}_{4}$ fluxes were observed during the different stages of development of the rice crop. The magnitude of the fluxes is in good agreement with results obtained at other Italian rice paddy fields. Mean seasonal $\mathrm{CH}_{4}$ emission rates reported in Butterbach-Bahl et al. (1997) were $11.4 \mathrm{mg} \mathrm{CH}_{4} \mathrm{~m}^{-2} \mathrm{~h}^{-1}$ while mean daytime fluxes in Werle and Kormann (2001) were around $0.25 \mu \mathrm{mol} \mathrm{m}^{-2} \mathrm{~s}^{-1}$ (14.5 $\mathrm{mg} \mathrm{CH}_{4} \mathrm{~m}^{-2} \mathrm{~h}^{-1}$ ), both similar to the mean $\mathrm{CH}_{4}$ fluxes observed in our experiment during the rice growing season (11.36 $\mathrm{mg} \mathrm{CH}_{4} \mathrm{~m}^{-2} \mathrm{~h}^{-1}$ ). Our results are also comparable with studies in other rice paddy fields in different parts of the globe (Simpson et al., 1995), ranging from 0.36 to $27.36 \mathrm{mg}$ $\mathrm{CH}_{4} \mathrm{~m}^{-2} \mathrm{~h}^{-1}$ in India (Parashar et al., 1991; Mitra, 1992) to $28.6 \mathrm{mg} \mathrm{CH}_{4} \mathrm{~m}^{-2} \mathrm{~h}^{-1}$ in China (Wang et al., 1990).

The net ecosystem $\mathrm{CH}_{4}$ flux depends on the relative rates of $\mathrm{CH}_{4}$ production and oxidation and therefore on the soil redox potential. At the investigated site the soil remains water logged during most of the year, due to its high clay content and as a result of either managed flooding or rainfall. Therefore, we assume that the conditions were favourable for methanogenesis during a large part of the experimental period, and favourable for net $\mathrm{CH}_{4}$ oxidation only in the spring before submersion. However, $\mathrm{CH}_{4}$ oxidation in the surface of a flooded rice field may consume about $80 \%$ of the gross $\mathrm{CH}_{4}$ flux (Conrad and Rothfuss, 1991). The measured net flux is the result of simultaneous production and consumption processes, which is emitted through different pathways: plant-mediated transport through the aerenchymal system of rice plants is responsible for $90 \%$ of the emission (Cicerone and Shetter, 1981; Holzapfel-Pschorn and Seiler, 1986; Schütz et al., 1989; Butterbach-Bahl et al., 1997), $8 \%$ of $\mathrm{CH}_{4}$ is released through bubbles and $2 \%$ comes from the diffusion through the water column. The methodologies applied in this study do not allow the differenciation of the underlaying processes.

Even if the soil was waterlogged during a large fraction of the observation time, high $\mathrm{CH}_{4}$ fluxes were produced at specific periods, when other environmental conditions were 
favourable (e.g. temperature) and in particular when rice plants were well developed. The relationship between $\mathrm{CH}_{4}$ fluxes and water table depth (Fig. 4) shows that in this rice field, a minimum level of the water table $(10-12 \mathrm{~cm})$ is required to observe large emissions. The soil submersion creates the anaerobic conditions needed for the methanogenesis (Neue, 1993) and limits the possibility for $\mathrm{CH}_{4}$ oxidation. Moreover, it favours the growth of rice plants, which are responsible for more than $90 \%$ of the methane transport from the soil to the atmosphere (Inubushi et al., 1992)

The results reported in Fig. 4 support the opinion of Christensen et al. (2003), who suggested that the water table height operates like a general "on-off switch" for $\mathrm{CH}_{4}$ emission. In ecosystems with relatively high water table, small fluctuations of the water level have only minor effects on $\mathrm{CH}_{4}$ emissions. However, the reduction of the water table below a critical threshold could lead to a substantial reduction of $\mathrm{CH}_{4}$ emissions. Christensen et al. (2003) observed that in wetlands, once the water level was aproximately $10 \mathrm{~cm}$ above the soil surface, other variables were responsible for the variability on the emissions. Even though our experiment was not specifically designed to elucidate the effect of the water table (other variables changed at the same time as the water table and for some of the water table ranges there is a lack of flux observations), a similar threshold of $10-12 \mathrm{~cm}$ as the limit for large $\mathrm{CH}_{4}$ production was observed. Above this threshold, small variations of the water table did not affect the emissions, which remained high anyway. Below this threshold, emissions were drastically reduced. However, in our experiment the high water table coincided with the phenological stage in which rice plants have fully developed the aerenchyma and therefore are very effective in transporting $\mathrm{CH}_{4}$ to the atmosphere. The apparent effect of the water table reported in Fig. 4 might therefore be due also to the close correlation between water level and plant development in rice paddy fields.

Similarly to what was observed by Zou et al. (2005) in rice paddies in China, these results suggest that the water table depth could be potentially used as a management option to control $\mathrm{CH}_{4}$ emissions from rice fields, as lowering the water table might considerably reduce emissions. However, the reductions of the water table can also trigger large episodic bursts of $\mathrm{CH}_{4}$ emission from soil pores (Bubier and Moore, 1994). The results from this experiment are not sufficient to explore this management option and further studies are therefore needed to develop optimal strategies for the management of the water table in order to control emissions of $\mathrm{CH}_{4}$ and minimize any possible negative effects on crop yield.

Another important variable explaining $\mathrm{CH}_{4}$ fluxes during the different stages of development of the plants was soil temperature. Positive relations between emission of $\mathrm{CH}_{4}$ and temperature have also been reported among other by (Pattey et al., 2006; Long et al., 2010; Schrier-Uijl et al., 2010). On the contrary Schutz et al. (1990) and Gogoi et al. (2005) did not find any positive correlation between $\mathrm{CH}_{4}$ emission and temperature during the growing season, suggesting that the water table in the field, acts as an insulating body which keps the soil temperature fairly uniform. In our experiment the relationships of methane emissions with soil temperature were especially important in the vegetative and ripening periods, when the water table was not very high (below the $10 \mathrm{~cm}$ threshold in the vegetative and half of the ripening periods). However, as in our experimental site ambient temperature oscillated much more than in the rice field studied by Gogoi et al. (2005), the water table could not completely compensate the oscillations of temperature, resulting in a significant temperature control also during the reproductive period.

Gogoi et al. (2005) in rice cultivars in India, observed that $\mathrm{CH}_{4}$ emissions were substantially influenced by crop phenology and growth, as they showed strong positive relationship with parameters related to the development of the canopy such as leaf number or leaf area index. In view of these results, the analysis of methane emissions in the following sections has been performed separately for these different stages of the crop development.

\subsection{Diurnal variation of $\mathrm{CH}_{4}$ fluxes}

The occurrence of a diurnal cycle in $\mathrm{CH}_{4}$ fluxes has been observed in previous studies in peatlands and submerged ecosystems (Suyker et al., 1996; Kim et al., 1998; Long et al., 2010). Some other studies have already shown that there is diurnal variation on the fluxes in rice paddy fields, with higher fluxes observed during the afternoon (Simpson et al., 1995; Satpathy et al., 1997; Miyata et al., 2000; Tseng et al., 2010). Simpson et al. (1995) measured similar daily peak emissions as in our experiment $\left(8 \mu \mathrm{g} \mathrm{CH}_{4} \mathrm{~m}^{-2} \mathrm{~s}^{-1}\right.$ or $0.5 \mu \mathrm{mol} \mathrm{m}{ }^{-2} \mathrm{~s}^{-1}$, see Fig. 5). Holzapfel-Pschorn and Seiler (1986) and Werle and Kormann (2001) already observed a diurnal variation in $\mathrm{CH}_{4}$ emissions in Italian rice paddy fields. Similarly to our results, they observed maximum amplitudes in the fluxes during the first stages of development of the plants (first half of the vegetative period). Different diurnal trends and environmental controls have been reported for peatland pastures. Baldocchi et al. (2011) observed a diurnal variation of $\mathrm{CH}_{4}$ fluxes with emissions peaking at night probably due to the spatial heterogeneity of the sources (e.g. cattle emitting $\mathrm{CH}_{4}$ around the tower during night) or to micrometeoreological causes (e.g. collapse of the nocturnal boundary layer followed by an extension of the flux footprint under stable stratification to areas with higher fluxes).

In not submerged ecosystems, such as the boreal forest in Finland investigated by Rinne et al. (2007), no diurnal cycle in $\mathrm{CH}_{4}$ fluxes was observed. Therefore, the occurrence of a water table seems to be prerequisite to observe a clear diurnal cycle in emissions. The peak of $\mathrm{CH}_{4}$ fluxes in the late evening, which is the time of the day when the water layer reaches the highest temperatures, make us suppose that the environmental control of the diurnal cycle of emission is water temperature. We cannot confirm this hypothesis as 
the temperature of the water above the soil surface was not measured, and the observed soil temperature is marginally affected by daily variations in air temperature. However, in other studies where this daily cycle was observed, it was suggested that diurnal changes in $\mathrm{CH}_{4}$ emission were only partially explained by temperature changes (Schutz et al., 1990) so other mechanisms might be responsible of the diurnal variation in $\mathrm{CH}_{4}$ fluxes during the periods of high $\mathrm{CH}_{4}$ emissions. The fact that the relations between fluxes and soil temperature is evident only when data are separated for day and night suggests that processes influenced by light availability may interfere with $\mathrm{CH}_{4}$ net emissions. Nouchi et al. (1990) already observed that stomata are not responsible of the release of $\mathrm{CH}_{4}$ from rice plants while Mariko et al. (1991) observed that the aerenchymal tissue of rice plant is indeed the most important path for the transport of $\mathrm{CH}_{4}$ from the anoxic soil to the atmosphere. The effect of stomata control on diurnal variation of fluxes has therefore to be excluded. Frenzel et al. (1992) observed that rice plants also serve as a conduit for atmospheric $\mathrm{O}_{2}$ into the rizosphere, resulting in decreased rates of $\mathrm{CH}_{4}$ emission from the soil into the atmosphere (Holzapfel-Pschorn and Seiler, 1986). Following this observation, changes in the net $\mathrm{CH}_{4}$ fluxes might be influenced by the efficiency in $\mathrm{CH}_{4}$ oxidation in the rhizosphere (Frenzel et al., 1992).

Other studies report that a reduction in solar radiation results in a decrease of the emissions (Sass and Cicerone, 2002). Subsequently, Keppler et al. (2006) suggested that an explanation for the relationship between emission, leaf biomass and solar radiation could be the "in situ" formation of $\mathrm{CH}_{4}$ in the plants tissues, through an unknown process distinct from the widely accepted process requiring anoxic soil conditions.

Another process which may modulate the diurnal cycle of fluxes is the convective flow generated by pressure gradients in the plant and associated with air-leaf temperature and humidity gradients. Pressure gradients driven by diurnal variation in light availability may therefore produce variation on the emissions according to solar radiation (Dacey, 1981; Brix et al., 1992). As an additional process, it has also been shown that the $\mathrm{CH}_{4}$ dissolved in the soil solution could be released to the atmosphere via the transpiration flux (Nisbet et al., 2009) and thus contribute to the diurnal variation.

\subsection{Comparison between chamber and eddy covariance measurements of $\mathrm{CH}_{4}$}

Chamber-based measurements are very sensitive because of the large increase in gas concentration in the headspace (Denmead, 2008), but they are often criticised because of uncertainties due to pressure artefacts and temperature effects (Hutchinson and Livingston, 2002; Rochette and EriksenHamel, 2008), discontinuity of measurements and lack of spatial integration (Flechard et al., 2007). Despite these limitations the chamber technique is the most commonly used for measuring $\mathrm{CH}_{4}$ fluxes from ecosystems. Lately, the number of studies of $\mathrm{CH}_{4}$ fluxes with EC has increased, due to the recent availability of instruments able to measure $\mathrm{CH}_{4}$ concentration at the sampling rates and response time required by this technique. EC offers the advantage of obtaining continuous data integrated over larger areas with no alteration of the ecosystem microclimatology. However, recent studies have shown that the measurement of $\mathrm{CH}_{4}$ fluxes may challenge the assumption of a horizontally homogeneous source or sink, and it has turned out to be much more complicated than the measurement of other fluxes such as carbon dioxide or water (Baldocchi et al., 2011). Nevertheless, it is expected that studies on $\mathrm{CH}_{4}$ fluxes with $\mathrm{EC}$ will soon become more popular, and it is therefore relevant to compare results obtained with the two different techniques.

Our comparisons of the two methods show an overestimation of fluxes when measured with chambers, similarly to the results reported by Bekku et al. (1995) and Werle and Kormann, (2001). The difference between the two techniques, as shown by Blandt Altman test, is increasing at higher $\mathrm{CH}_{4}$ fluxes. It is therefore likely that in systems with lower $\mathrm{CH}_{4}$ emissions, both measurement techniques would lead to more consistent results.

One of the possible reasons for the higher $\mathrm{CH}_{4}$ fluxes measured with the chambers may be the temperature increase during the closure of the chamber. Even if the effect of temperature on the molar weight is taken into account in the calculation of the fluxes, the possible increase of $\mathrm{CH}_{4}$ release through plants due to the increasing temperature inside the chamber cannot be accounted for.

Other possible reason for the mismatch of the observations is the non-homogenous surface cover or soil characteristics within the field. Chambers measure fluxes from a plot with optimal development of plants, while EC integrates fluxes from areas of the field where the vegetation might not be homogeneusly developed. To compensate for the spatial heterogeneity, Schrier-Ujil et al. (2010) suggested that the comparison of methods has to be done by weighting the emissions of different landscape elements. Wang et al. (2010) also pointed that the main reason for the disagreement between both techniques might be the complex footprint covered by the EC and the spatial heterogeneity for the scaling up of chamber measurements.

The difference between the $26 \%$ bias observed in the regression of single observations and the $30 \%$ difference of seasonally cumulated fluxes is due to the linear interpolation of chamber fluxes (usually measured at noon) that ignores the diurnal variation of emission as observed with EC. Alternatively, cumulative emissions can be calculated with a model that accounts for the temperature dependence of fluxes, as proposed by Schrier-Ujil et al. (2010) for $\mathrm{CO}_{2}$ and $\mathrm{CH}_{4}$. In our experiment, we decided to adopt the linear interpolation since this is the method more commonly used for the temporal integration of emissions. The differences we observed between the two techniques were however smaller than the 
$55.1 \%$ reported by Schrier-Ujil et al. (2010) when they did not take into account temperature and landscape heterogeneity.

Parkin (2008) observed that the sampling frequency had a great influence on the estimation of cumulative fluxes, and that as the time interval between sampling increased, the deviation in the estimated cumulative also increased. In our experiment even larger differences between measurement tecniques were observed during sub-periods when the series of EC data was continuous, up to $80 \%$ higher for chamber $\mathrm{CH}_{4}$ emissions, similarly to the values reported by Werle and Kormann (2001) who observed differences between 60 and $90 \%$.

Some authors have pointed out that the use of liner regressions to estimate fluxes from chamber concentrations could result in an underestimation of the fluxes and suggest the use of the slope intercept method (Kroon et al., 2008). This underestimation is caused by a decrease in the concentration gradient between the chamber and the soil atmosphere, due to the increased concentration in the chamber headspace. However, Schrier-Ujil et al. (2010), who compared the linear regression and the slope intercept methods for the calculation of the fluxes, observed $4 \%$ higher fluxes with the slope intercept method, but these differences were not significant. If this effect would have taken place in our chambers, even higher fluxes would have been estimated with the chambers.

Chambers measurements are prone to other possible sources of error, such as the possible inaccuracies derived from the analysis of $\mathrm{CH}_{4}$ concentration by gas chromatography, or the imperfect mixing in the chamber headspace (Liu and Si, 2009; Christiansen et al., 2011). Hutchinson et al. (2000) observed that the use of chambers alters the atmospheric mixing processes at the soil-atmosphere interface, resulting in either enhanced or suppressed gas exchange rates between $-30 \%$ to $+32 \%$ of the pre-deployment flux.

Similarly to what was observed in previous studies (Werle and Kormann, 2001) we think that the observed mismatch between the two measurement techniques is probably due to a combination of several issues explained above, resulting in a general over-estimation of the fluxes by the chambers combined with a potential underestimation of fluxes measured by EC.

\section{Conclusions}

Diurnal and seasonal variations of $\mathrm{CH}_{4}$ fluxes were observed in an Italian rice paddy field. The seasonal variation seemed to be mainly triggered by the height of the water table, which above a certain threshold $(10-12 \mathrm{~cm})$ favoured the production of $\mathrm{CH}_{4}$. Further studies should be carried out to assess if an adequate management of the water table could lead to a decrease in the emissions. The development of rice plants strongly influenced $\mathrm{CH}_{4}$ emissions, possibly because $\mathrm{CH}_{4}$ is mainly released through plant aerenchyma. Temperature has been found to be another factor which strongly influenced emissions, mainly during the vegetative and ripening periods. Several processes could be responsible of the diurnal pattern of the emissions, which was especially important during the first half of the vegetative period. Diurnal pattern in $\mathrm{CH}_{4}$ fluxes with maxima in evening seems to happen in systems where a water table is present, possibly as an effect of the diurnal cycle of water temperature.

The comparison between the data sets obtained with EC and chambers showed that both data series followed a similar temporal pattern. However, $\mathrm{CH}_{4}$ fluxes measured with chambers were larger, and the differences between techniques increased during periods of higher emissions. Estimation of seasonal cumulated emissions based on chamber measurements resulted in higher fluxes than with EC, as a consequence of the overestimation with the chambers or of the potential underestimation of ecosystem fluxes by the EC technique. Further studies based on the EC technique will provide detailed information on the dynamics and controls of the net ecosystem $\mathrm{CH}_{4}$ flux, which will enhance the development of effective management strategies for the reduction of $\mathrm{CH}_{4}$ emissions from rice paddy fields.

Acknowledgements. This research was supported by the Nitroeurope-IP project and the rice field Castellaro is part of the Nitroeurope-IP level 3 network of intensive monitoring sites. The authors would like to thank the owner of the rice field for allowing us to carry out the measurements and for the support given with the field activities. We would also like to thank M. Duerr for her technical assistance in the field and laboratory.

Edited by: A. R. Mosier

\section{References}

Altman, D. G. and Bland, J. M.: Measurement in Medicine: the Analysis of Method Comparison Studies, The Statistician, 32, 307-317, 1983.

Aubinet, M., Grelle, A., Ibrom, A., Rannik, U., Moncrieff, J., Foken, T., Kowalski, A. S., Martin, P. H., Berbigier, P., Bernhofer, C., Clement, R., Elbers, J., Granier, A., Grãnwald, T., Morgenstern, K., Pilegaard, K., Rebmann, C., Snijders, W., Valentini, R., and Vesala, T.: Estimates of the Annual Net Carbon and Water Exchange of Forests: The EUROFLUX Methodology, Adv. Ecol. Res., 30, 113-175, 2000.

Baldocchi, D. D., Hicks, B. B., and Meyers, T. P.: Measuring biosphere-atmosphere exchanges of biologically related gases with micrometeorological methods, Ecology, 69, 1331-1340, 1988.

Baldocchi, D., Valentini, R., Running, S., Oechel, W., and Dahlman, R.: Strategies for measuring and modelling carbon dioxide and water vapour fluxes over terrestrial ecosystems, Global Change Biol., 2, 159-168, 1996.

Baldocchi, D., Detto, M., Sonnentag, O., Verfaillie, J., Teh, Y. A., Silver, W., and Kelly, N. M.: The challenges of measuring methane fluxes and concentrations over a peatland pasture, 
Agric. For. Meteorol., doi:10.1016/j.agrformet.2011.04.013, in press., 2011.

Bekku, Y., Koizumi, H., Nakadai, T., and Iwaki, H.: Measurement of soil respiration using closed chamber method: An IRGA technique, Ecol. Res., 10, 369-373, 1995.

Brix, H., Sorrell, B. K., and Orr, P. T.: Internal pressurization and convective gas flow in some emergent freshwater macrophytes, Limnol. Oceanogr., 37, 1420-1433, 1992.

Bubier, J. L. and Moore, T. R.: An ecological perspective on methane emissions from northern wetlands, Trends Ecol. Evol., 9, 460-464, 1994.

Butterbach-Bahl, K., Papen, H., and Rennenberg, H.: Impact of gas transport through rice cultivars on methane emission from rice paddy fields, Plant Cell Environ., 20, 1175-1183, 1997.

Christensen, T. R., Ekberg, A., Strom, L., Mastepanov, M., Panikov, N., Mats, O., Svensson, B. H., Nykanen, H., Martikainen, P. J., and Oskarsson, H.: Factors controlling large scale variations in methane emissions from wetlands, Geophys. Res. Lett., 30, 6761, 2003.

Christiansen, J., Korhonen, J., Juszczak, R., Giebels, M., and Pihlatie, M.: Assessing the effects of chamber placement, manual sampling and headspace mixing on $\mathrm{CH} 4$ fluxes in a laboratory experiment, Plant Soil, 343, 171-185, 2011.

Cicerone, R. J. and Shetter, J. D.: Sources of atmospheric methane: Measurements in rice paddies and a discussion, J. Geophy. Res., 86, 7203-7209, 1981.

Cole, V., Cerri, C., Minami, K., Mosier, A., Rosenberg, N., and Sanerack, D.: Agricultural options for mitigation of greenhouse gas emissions, in: Climate Change, edited by: Houghton, R. A. J. T., Meria Filho, L. G., Callander, B. A., Harris, N., Kettenber, A., and Maskell, K., Cambridge University Press, Cambridge, UK, 745-771, 1995.

Conrad, R. and Rothfuss, F.: Methane oxidation in the soil surface layer of a flooded rice field and the effect of ammonium, Biol. Fertility Soils, 12, 28-32, 1991.

Dacey, J. W. H.: Pressurized ventilation in the yellow waterlily, Ecology, 62, 1137-1147, 1981.

Damm, A., Elber, J., Erler, A., Giol, G., Hamdi, K., Hutjes, R., Kosvancova, M., Meroni, M., Miglietta, F., Moersch, A., Moreno, J., Schickling, A., Sonnenschein, R., Udelhoven, T., van der Linden, S., Hostert, P., and Rascher, U.: Remote sensing of suninduced fluorescence to improve modeling of diurnal courses of gross primary production (GPP), Global Change Biol., 16, 171$186,2010$.

Denmead, O. T.: Approaches to measuring fluxes of methane and nitrous oxide between landscapes and the atmosphere, Plant. Soil., 309, 5-24, 2008.

Detto, M., Verfaillie, J., Anderson, F., Xu, L., and Baldocchi, D.: Comparing laser-based open- and closed-path gas analyzers to measure methane fluxes using the eddy covariance method, Agric. For. Meteorol., 151, 1312-1324, doi:10.1016/j.agrformet.2011.05.014, 2011.

Dlugokencky, E. J., Steele, L. P., Lang, P. M., and Masarie, K. A.: The growth rate and distribution of atmospheric methane, J. Geophy. Res., 99, 17021-17043, 1994.

Etheridge, D. M., Steele, L. P., Francey, R. J., and Langenfelds, R. L.: Atmospheric methane between 1000 A.D. and present: Evidence of anthropogenic emissions and climatic variability, J. Geophys. Res. Atmos., 103, 15979-15993, 1998.
Falge, E., Baldocchi, D., Olson, R., Anthoni, P., Aubinet, M., Bernhofer, C., Burba, G., Ceulemans, R., Clement, R., Dolman, H., Granier, A., Gross, P., Grãnwald, T., Hollinger, D., Jensen, N. O., Katul, G., Keronen, P., Kowalski, A., Ta Lai, C., Law, B. E., Meyers, T., Moncrieff, J., Moors, E., William Munger, J., Pilegaard, K., Rannik, Ã., Rebmann, C., Suyker, A., Tenhunen, J., Tu, K., Verma, S., Vesala, T., Wilson, K., and Wofsy, S.: Short communication: Gap filling strategies for long term energy flux data sets, Agric. For. Meteorol., 107, 71-77, 2001.

FAO: World Reference Base for Soil Resources, Food and Agriculture Organization of the United Nation, Rome, 1998.

FAO: FAO Rice information, in, edited by: The Secretariat of the International Rice Commission - Food and Agriculture Organization of the United Nations, Rome, 2002.

Ferrero, A.: Rice scenario in the European Union, Cahiers Agricultures, 16, 272-277, doi:10.1684/agr.2007.0108, 2007.

Ferretti, D. F., Miller, J. B., White, J. W. C., Etheridge, D. M., Lassey, K. R., Lowe, D. C., MacFarling Meure, C. M., Dreier, M. F., Trudinger, C. M., Van Ommen, T. D., and Langenfelds, R. L.: Atmospheric science: Unexpected changes to the global methane budget over the past 2000 years, Science, 309, 1714$1717,2005$.

Flechard, C. R., Ambus, P., Skiba, U., Rees, R. M., Hensen, A., van Amstel, A., Dasselaar, A. v. d. P. v., Soussana, J. F., Jones, M., Clifton-Brown, J., Raschi, A., Horvath, L., Neftel, A., Jocher, M., Ammann, C., Leifeld, J., Fuhrer, J., Calanca, P., Thalman, E., Pilegaard, K., Di Marco, C., Campbell, C., Nemitz, E., Hargreaves, K. J., Levy, P. E., Ball, B. C., Jones, S. K., van de Bulk, W. C. M., Groot, T., Blom, M., Domingues, R., Kasper, G., Allard, V., Ceschia, E., Cellier, P., Laville, P., Henault, C., Bizouard, F., Abdalla, M., Williams, M., Baronti, S., Berretti, F., and Grosz, B.: Effects of climate and management intensity on nitrous oxide emissions in grassland systems across Europe, Agr. Ecosys. Environ., 121, 135-152, 2007.

Foken, T. and Wichura, B.: Tools for quality assessment of surfacebased flux measurements, Agric. For. Meteorol., 78, 83-105, 1996.

Frenzel, P., Rothfuss, F., and Conrad, R.: Oxygen profiles and methane turnover in a flooded rice microcosm, Biol. Fertility Soils, 14, 84-89, 1992.

Gash, J. H. C. and Culf, A. D.: Applying a linear detrend to eddy correlation data in realtime, Bound-Lay. Meteorol., 79, 301-306, 1996.

Gogoi, N., Baruah, K. K., Gogoi, B., and Gupta, P. K.: Methane emission characteristics and its relations with plant and soil parameters under irrigated rice ecosystem of northeast India, Chemosphere, 59, 1677-1684, 2005.

Goulden, M. L., Munger, J. W., Fan, S. M., Daube, B. C., and Wofsy, S. C.: Measurements of carbon sequestration by longterm eddy covariance: Methods and a critical evaluation of accuracy, Global Change Biol., 2, 169-182, 1996.

Hendriks, D. M. D., Dolman, A. J., van der Molen, M. K., and van Huissteden, J.: A compact and stable eddy covariance set-up for methane measurements using off-axis integrated cavity output spectroscopy, Atmos. Chem. Phys., 8, 431-443, doi:10.5194/acp-8-431-2008, 2008.

Hendriks, D. M. D., van Huissteden, J., and Dolman, A. J.: Multi-technique assessment of spatial and temporal variability of methane fluxes in a peat meadow, Agric. For. Meteorol., 150, 
757-774, 2009.

Herbst, M., Friborg, T., Ringgaard, R., and Soegaard, H.: Interpreting the variations in atmospheric methane fluxes observed above a restored wetland, Agric. For. Meteorol., 151, 841-853 2011.

Hillel, D.: Introduction to Soil Physics, Academic Press, San Diego, 392 pp., 1982.

Holzapfel-Pschorn, A. and Seiler, W.: Methane emissions during a cultivation period from an Italian rice paddy, J. Geophys. Res., 91, 11803-11814, 1986.

Houghton, J. T., MeiraFilho, L. G., Callander, B. A., Harris, N., Kattenberg, A., and Maskell, K.: The Science of Climate Change, Cambridge University Press, Cambridge, UK 1995.

Hutchinson, G. L., Livingston, G. P., Healy, R. W., and Striegl, R. G.: Chamber measurement of surface-atmosphere trace gas exchange: Numerical evaluation of dependence on soil, interfacial layer, and source/sink properties, J. Geophys. Res-Atmos., 105, 8865-8875, 2000.

Hutchinson, G. L. and Livingston, G. P.: Soil-atmosphere gas exchange, in: Methods of soil analysis. Part 4, edited by: Dane, J. H. and Topp, G. C., SSSA Book Series, Madison, WI, 11591182, 2002.

Inubushi, K., Muramatsu, Y., and Umerayasi, M.: Influence of percolation on methane emission from flooded paddy soil, Jpn. J. Soil Sci. Plant Nutr., 63, 184-189, 1992.

IPCC: Good practice guidance for land use, land-use change and forestry. $\mathrm{CH} 4$ emissions from rice agriculture., in: IPCC National Greenhouse Gas Inventories, edited by: Intergovermental Pannel on Climate Change, Kanagawa, Japan, 2003.

Keppler, F., Hamilton, J. T. G., BraÃŸ, M., and Rockmann, T.: Methane emissions from terrestrial plants under aerobic conditions, Nature, 439, 187-191, 2006.

Kim, J., Verma, S. B., and Billesbach, D. P.: Seasonal variation in methane emission from a temperate Phragmites-dominated marsh: effect of growth stage and plant-mediated transport, Glob. Change Biol., 5, 433-440, 1998.

Kroon, P. S., Hensen, A., Van Den Bulk, W. C. M., Jongejan, P. A. C., and Vermeulen, A. T.: The importance of reducing the systematic error due to non-linearity in $\mathrm{N}_{2} \mathrm{O}$ flux measurements by static chambers, Nutr. Cycl. Agroecosys., 82, 175-186, 2008.

Kroon, P. S., Hensen, A., Jonker, H. J. J., Ouwersloot, H. G., Vermeulen, A. T., and Bosveld, F. C.: Uncertainties in eddy covariance flux measurements assessed from $\mathrm{CH}_{4}$ and $\mathrm{N}_{2} \mathrm{O}$ observations, Agric. For. Meteorol., 150, 806-816, 2009.

Lancashire, P. D., Bleiholder, H., Langeluddecke, P., Stauss, R., van den Boom, T., Weber, E., and Witzenberger, A.: A uniform decimal code for growth stages of crops and weeds, Ann. Appl. Biol., 119, 561-601, 1991.

Leip, A.: Nitrous oxide $\left(\mathrm{N}_{2} \mathrm{O}\right)$ emissions from a coastal catchment in the Delta of the Po river. Measurement and modeling of fluxes from a Mediterranean lagoon and agricultural soil, Office for Official Publications of the European Communities, Luxembourg, 2000.

Liu, G. and Si, B. C.: Multi-layer diffusion model and error analysis applied to chamber-based gas fluxes measurements, Agric. For. Meteorol., 149, 169-178, 2009.

Long, K. D., Flanagan, L. B., and Cai, T.: Diurnal and seasonal variation in methane emissions in a northern Canadian peatland measured by eddy covariance, Glob. Change Biol., 16, 2420$2435,2010$.
MacKenzie, A. F., Fan, M. X., and Cadrin, F.: Nitrous oxide emission in three years as affected by tillage, corn- soybean-alfalfa rotations, and nitrogen fertilization, J. Environ. Qual., 27, 698703, 1998.

Mariko, S., Harazano, Y., Owa, N., and Nouchi, I.: Methane in flooded soil water and the emission through rice plants to atmosphere, Environ. Exp. Bot., 31, 343-350, 1991.

McMillen, R. T.: An eddy correlation technique with extended applicability to non-simple terrain, Bound-Lay. Meteorol., 43, 231245, 1988.

Meier, U.: Growth Stages of Mono- and Dicotyledonous Plants in: Biologische Bundesanstalt, Bundessortenamt und Chemische Industrie $[\mathrm{BBCH}]$ - Monograph, Blackwell Wissenschafts-Verlag, Berlin, 1997.

Mitra, A. P.: Global Change: Greenhouse gas emissions in India, Sci. Rep. 2, Counc. Sci. Ind. Res. Minis. Environ. Forest, 1992.

Miyata, A., Leuning, R., Denmead, O. T., Kim, J., and Harazono, Y.: Carbon dioxide and methane fluxes from an intermittently flooded paddy field, Agric. For. Meteorol., 102, 287-303, 2000.

Mosier A.R: Gas flux measurement techniques with special reference to techniques suitable for measurements over large ecologically uniform areas, in: Soils and the Greenhouse Effect., edited by: Bouwman, A. F., Wiley, Chichester, 289-301, 1990.

Neftel, A., Spirig, C., and Ammann, C.: Application and test of a simple tool for operational footprint evaluations, Environ. Pollut., 152, 644-652, 2008.

Neue, H. U.: Methane emission from rice fields, Bioscience, 43, 466-475, 1993.

Nisbet, R. E. R., Fisher, R., Nimmo, R. H., Bendall, D. S., Crill, P. M., Gallego-Sala, A. V., Hornibrook, E. R. C., López-Juez, E., Lowry, D., Nisbet, P. B. R., Shuckburgh, E. F., Sriskantharajah, S., Howe, C. J., and Nisbet, E. G.: Emission of methane from plants, Proc. Roy. Soc., 276, 1347-1354, 2009.

Nouchi, I., Mariko, S., and Aoki, K.: Mechanism of methane transport from the rhizosphere to the atmosphere through rice plants, Plant. Physiol., 94, 59-66, 1990.

Parashar, D. C., Rai, J., Gupta, P. K., and Singh, N.: Parameters affecting methane emission from paddy fields, Ind. J. Radio Space Phys., 20, 12-17, 1991.

Parkin, T. B.: Effect of Sampling Frequency on Estimates of Cumulative N20 Emissions, J. Environ. Qual., 37, 1390-1395, 2008.

Pattey, E., Strachan, I. B., Desjardins, R. L., Edwards, G. C., Dow, D., and MacPherson, J. I.: Application of a tunable diode laser to the measurement of $\mathrm{CH}_{4}$ and $\mathrm{N}_{2} \mathrm{O}$ fluxes from field to landscape scale using several micrometeorological techniques, Agric. For. Meteorol., 136, 222-236, 2006.

Rinne, J., Riutta, T., Pihlatie, M., Aurela, M., Haapanala, S., Tuovinen, J. P., Tuittila, E. S., and Vesala, T.: Annual cycle of methane emission from a boreal fen measured by the eddy covariance technique, Tellus B, 59, 449-457, 2007.

Rochette, P. and Eriksen-Hamel, N. S.: Chamber measurements of soil nitrous oxide flux: Are absolute values reliable?, Soil Sci. Soc. Am. J., 72, 331-342, 2008.

Rossini, M., Meroni, M., Migliavacca, M., Manca, G., Cogliati, S., Busetto, L., Picchi, V., Cescatti, A., Seufert, G., and Colombo, R.: High resolution field spectroscopy measurements for estimating gross ecosystem production in a rice field, Agric. For. Meteorol., 150, 1283-1296, 2010.

Sass, R. L., Fisher, F. M., Turner, F. T., and Jund, M. F.: Methane 
emission from rice fields as influenced by solar radiation, temperature, and straw incorporation, Global Biogeochem. Cy., 5, 335-350, 1991.

Sass, R. L. and Cicerone, R. J.: Photosynthate allocations in rice plants: Food production or atmospheric methane?, Proceedings of the National Academy of Sciences of the United States of America, 99, 11993-11995, 2002.

Satpathy, S. N., Rath, A. K., Ramakrishnan, B., Rao, V. R., Adhya, T. K., and Sethunathan, N.: Diurnal variation in methane efflux at different growth stages of tropical rice, Plant Soil, 195, 267-271, 1997.

Schfitz, H., Hozapfel-Pschorn, A., Conrad, R., Renuenberg, H., and Seiler, W.: A three-year continuous record on the influences of daytime, season and fertiliser treatment on methane emission rates from an Italian rice paddy, J. Geophys. Res., 194, 1640516416, 1989.

Schrier-Uijl, A. P., Kroon, P. S., Hensen, A., Leffelaar, P. A., Berendse, F., and Veenendaal, E. M.: Comparison of chamber and eddy covariance-based $\mathrm{CO}_{2}$ and $\mathrm{CH}_{4}$ emission estimates in a heterogeneous grass ecosystem on peat, Agric. For. Meteorol., 150, 825-831, 2010.

Schutz, H., Seiler, W., and Conrad, R.: Influence of soil temperature on methane emission from rice paddy fields, Biogeochemistry, 5, 295-311, 1990 .

Schütz, H., Seiler, W., and Conrad, R.: Processes involved in formation and emission of methane in rice paddies, Biogeochemistry, 7, 33-53, 1989.

Shindell, D. T., Faluvegi, G., Koch, D. M., Schmidt, G. A., Linger, N., and Bauer, S. E.: Improved attribution of climate forcing to emissions, Science, 326, 716-718, 2009.
Simpson, I. J., Thurtell, G. W., Kidd, G. E., Lin, M., DemetriadesShah, T. H., Flitcroft, I. D., Kanemasu, E. T., Nie, D., Bronson, K. F., and Neue, H. U.: Tunable diode laser measurements of methane fluxes from an irrigated rice paddy field in the Philippines, J. Geophys. Res., 100, 7283-7290, 1995.

Suyker, A. E., Verma, S. B., Clement, R. J., and Billesbach, D. P.: Methane flux in a boreal fen: Season-long measurement by eddy correlation, J. Geophys. Res-Atmos., 101, 28637-28647, 1996.

Tseng, K. H., Tsai, J. L., Alagesan, A., Tsuang, B. J., Yao, M. H., and Kuo, P. H.: Determination of methane and carbon dioxide fluxes during the rice maturity period in Taiwan by combining profile and eddy covariance measurements, Agric. For. Meteorol., 150, 852-859, 2010.

Wang, M., Guan, D. X., Han, S. J., and Wu, J. L.: Comparison of eddy covariance and chamber-based methods for measuring $\mathrm{CO}_{2}$ flux in a temperate mixed forest, Tree Physiol., 30, 149$163,2010$.

Wang, M. X., Dai, A., Shen, R. X., Schutz, H., Rennenberg, H., Seiler, W., and $\mathrm{Wu}, \mathrm{H} .: \mathrm{CH}_{4}$ emission from a Chinese rice paddy field, Acta Meteorol. Sin., 4, 265-275, 1990.

Werle, P. and Kormann, R.: Fast chemical sensor for eddycorrelation measurements of methane emissions from rice paddy fields, Appl. Opt., 40, 846-858, 2001.

Zadok, C. J., Chang, T. T., and Konzak, C. F.: A decimal code for the growth stages of cereals, Weed Sci., 14, 415-421, 1974.

Zou, J., Huang, Y., Jiang, J., Zheng, X., and Sass, R. L.: A 3-year field measurement of methane and nitrous oxide emissions from rice paddies in China: Effects of water regime, crop residue, and fertilizer application Glob. Biogeochem. Cy., 19, doi:10.1029/2004GB002401, 2005. 